\title{
DESIGN AND PERFORMANCE EVALUATION OF A SOLAR DISTILLER UNIT FOR SEAWATER DESALINATION
}

\author{
H. S. Abdel-GaLIL
}

\section{ABSTRACT}

Water is the basic need to sustaining life on the earth for human. Solar still is a very simple solar device used for converting the available dirty/saline water into pure/potable water. This device can be fabricated easily with available materials. The maintenance is also cheap and no skilled labor is required to make it. This device can be suitable solution to solve drinking water problem. Various active methods were developed to overcome this problem. Here comparison is made between the solar still coupled with liquid flat plate collector as well as passive solar still. The obtained results indicated that maximum daily distilled water production of 5.3 and $4.2{\mathrm{~L} . \mathrm{m}^{-2}}^{-}$.day ${ }^{-1}$ were obtained in active and passive solar stills, respectively, at a water depth of $2.5 \mathrm{~cm}$ for the month of January. While

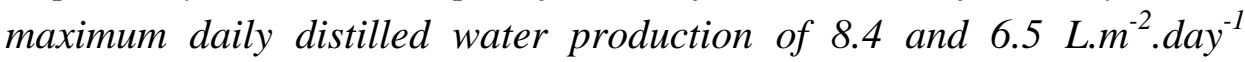
obtained in active and passive solar stills, respectively, at a water depth of $2.5 \mathrm{~cm}$ for the month of June. So that, solar still coupled with liquid flat plate collector increases the productivity of solar still by $26.2 \%$ and $29.2 \%$ for January and June, respectively. Lower the water depth in the solar still basin increases the productivity of solar distiller and solar radiation can also produce considerable effect on productivity.

\section{INTRODUCTION}

There is a severe lack of fresh water in the world today. Along with the deterioration of existing water supplies, the growing world

1 population leads to the assumption that two thirds of the population will lack sufficient fresh water by the year 2025 (UNEPb, 2000). Recently, considerable attention has been given to the use of renewable energy as sources for water desalination, especially in remote areas and islands, because of the high costs of fossil fuels, difficulties in obtaining it, attempts to conserve fossil fuels, interest in reducing air pollution, and the lack of electrical power in remote areas (Cesare, 2001).

* Assoc. Prof. of Agric. Eng., -Fac. of Agric.-Fayoum Univ. 
The use of solar energy for driving the desalination plant is also motivated in these areas by the fact that they imply a way for energy independence and water insurance (Kunze, H., 2001). The regions in most need of additional fresh water are the regions with the most intense solar radiation. For this reason, thermal solar energy in desalination processes should be the most promising application of renewable energies to seawater desalination (Garzia-Rodriguez $\mathbf{L}$, et al., 2002). The method of direct solar desalination is mainly suited for small production systems, such as solar stills in regions where the freshwater demand is less than $200 \mathrm{~m}^{3} /$ day (Garzia-Rodriguez, 2002). The simple solar still of the basin type is the oldest method and improvements in its design have been made to increase its efficiency (Naim, 2003). The areas with the severest water shortages are the warm, arid countries in the northern Africa and southern Asia within the latitudes $15-35^{\circ} \mathrm{N}$ (Hussain, 2003). Distillation is one of many processes that can be used for water purification. Solar radiation can be the source of heat energy. In this process, water is evaporated and this separating water vapour from dissolved substances, and is then considered as pure water (Hikmet, et al., 2005). A solar powered desalination unit produces potable water from saline water through direct or indirect methods of desalination powered by sunlight. Countries such as Australia, Italy and Egypt have adopted this system as an alternative source of water for the population (Qiblawey and Banat, 2008). Direct solar desalination produces distillate directly in the solar collector. An example would be a solar still which traps the sun's energy to obtain freshwater through the process of evaporation and condensation. Indirect solar desalination incorporates solar energy collection systems with conventional desalination systems such as multi-stage flash distillation, multiple effect evaporation, freeze separation or reverse osmosis to produce freshwater. The intermittent nature of sunlight and its variable intensity throughout the day makes predicting its efficiency difficult. However, incorporating a thermal energy storage system solves this problem and ensures constant performance even during non-sunlight hours and cloudy days, improving overall efficiency (Gude, et al., 2012). Bouker, et al., (2001) compared the performance of simple solar still with coupled one. They tested for all day productivity under clear sky 
conditions with different depth levels of brackish water for winter and summer period from Jan. to March (2000). They found that productivity in summer period varied from 4.01 to $4.34 \mathrm{~L} / \mathrm{m}^{2}$.day for simple basin and 8.02 to $8.07 \mathrm{~L} / \mathrm{m}^{2}$.day for coupled one. Singh, et al., (2004) done an experiment on active and passive solar still for different climate conditions like Chennal, Jodhpur, Kolkata and Mumbai on the basis of numerical computation. They found that annual yield significantly depends on water depth, condensing cover inclination for both active and passive solar still and annual yield for a given water depth increasing linearly with collector area for active solar still. Hitesh, et al., (2011) indicated that solar still coupled with flat plate collector increases the productivity of solar still by $35 \%$. On other hand, they found that lower the water depth increase the productivity of solar still and solar radiation can also produce considerable effect on productivity. Sethi, et al., (2013) designed a basin type double slope active solar still under forced circulation mode, and a performance evaluation were carried out for different water depths $(0.03 \mathrm{~m}, 0.04 \mathrm{~m}$ and $0.05 \mathrm{~m})$. The distillate output is maximum $4.82 \mathrm{~kg} / \mathrm{m}^{2}$ for water depth $0.03 \mathrm{~m}$ and minimum $4.36 \mathrm{~kg} / \mathrm{m}^{2}$ for water depth $0.05 \mathrm{~m}$. The maximum instantaneous thermal efficiency is 46.96 at water depth of $0.04 \mathrm{~m}$.

The major aim of this research is to design, test and performance evaluation of the solar distiller unit and to improve the output of single basin solar still coupled with liquid flat plate collector and same from the alone solar still.

\section{MATERIALS AND METHODS}

A. Experimental Set-up: The solar distillation unit was designed and constructed for seawater desalination under Fayoum climatic conditions. The latitude and longitude angles for the specific location are $29.18^{\circ}$ and $30.3^{\circ}$, respectively. Single slope solar still and flat plate collector are connected together and mounted on iron stands. The distillation unit consists of three main parts as shown in schematic diagram (Fig. 1), and the following are details of the components:

1. Feeding and storage tanks: Two Rectangular tanks of $0.8 \mathrm{~m}$ length, $0.5 \mathrm{~m}$ width and 1.0 height were made from stainless steel sheets. One of them (feeding tank) was for feeding seawater (dirty/saline water) to the 
liquid flat plate solar collector (LFPC) through control valve. The other one (storage tank) was for storing distilled water (pure/ potable water) which discharges from the single slope solar still.

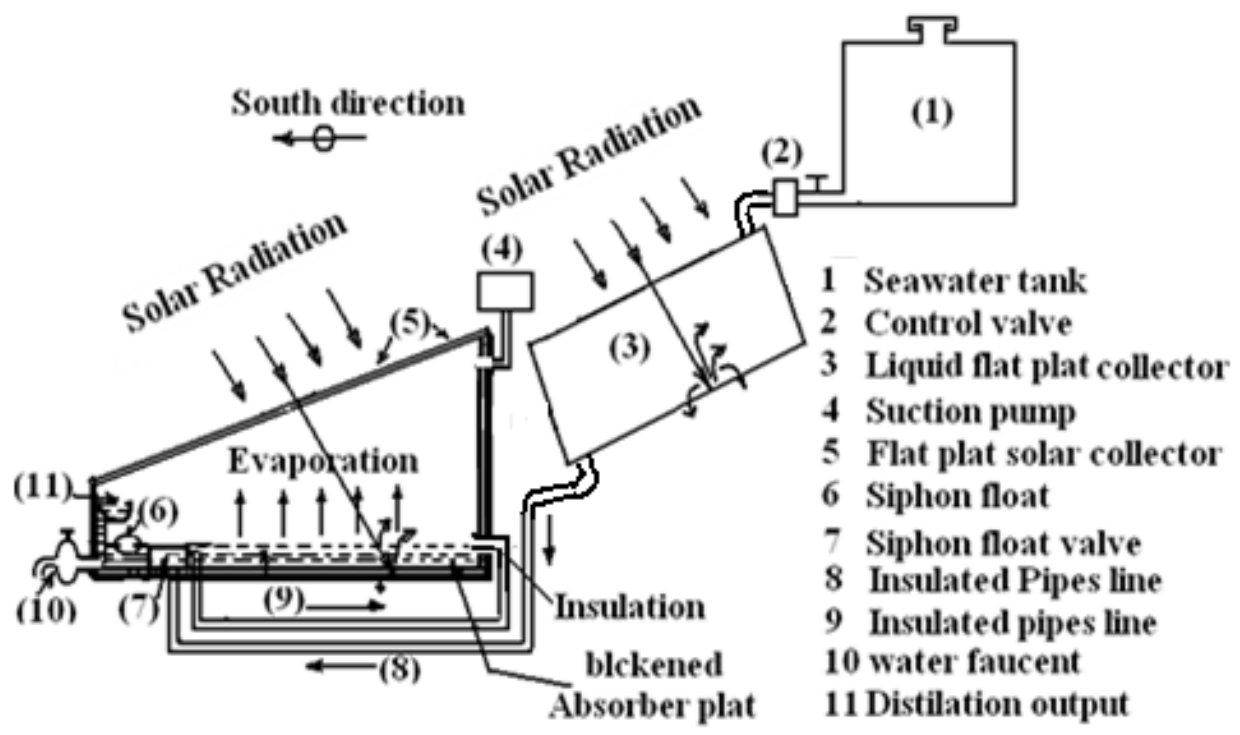

Fig. (1): Schematic Representation of the Experimental Set Up.

2. Liquid flat plate collector (LFPC): a simple liquid single cover flatplate collector is an insulated metal box with a glass cover (called the glazing) and a dark-colored absorber plate was constructed. This collector heats liquid at temperatures less than $80^{\circ} \mathrm{C}$. It has a surface area of $2.0 \mathrm{~m}^{2}$ (2.0 m length, $1.0 \mathrm{~m}$ width and $0.12 \mathrm{~m}$ depth). A fiber glass wool $(24 \mathrm{~kg}$. $\mathrm{m}^{-3}$ ) with thickness of $0.04 \mathrm{~m}$ and a thermal conductivity of $0.045 \mathrm{~W} . \mathrm{m}^{-}$ ${ }^{1} .{ }^{\circ} \mathrm{C}^{-1}$ were used to insulate the sides and bottom of the collector. The LFPC has a black/selected coated flat absorber plate (which having absorptivity and emissivity of 0.95 and 0.87 , respectively) with tubing in contact with the plate for passage of working fluid. The collector plate absorbs solar energy and transfers energy to water flowing through tubes. Transparent cover of glass sheet (4 $\mathrm{mm}$ thickness) is placed $7 \mathrm{~cm}$ on the upper side of absorber plate to reduce thermal losses. Absorber tubes made of copper are weld to the collector absorber plate placed at the top. The absorber surface reduces convection and radiation losses to the atmosphere and the back insulation to reduce the conduction losses. 
Set up consist total 6 numbers of copper tubes each of $2.0 \mathrm{~m}$ length placed at $16 \mathrm{~cm}$ from one another as shown in Fig. (2). The copper tubes are interconnected by using ' $\mathrm{T}$ ' and 'Elbow' joints. LFPC has two holes, which are used as a cooled water inlet and hot water outlet and to facilitate the attachment of LFPC to both feeding tank and the single slope solar still. The LFPC was mounted in a stationary position and orientated to face the south direction. It was tilted with the optimum tilt angle for the time of year in which the solar device is intended to operate.

3. Single slope solar still: As shown in Fig. (1), it is an airtight basin that contains the seawater (i.e. feed water). The body of basin is made up of a fiber reinforced plastic (FRP) to stand-up to the harsh conditions produced by water and sunlight. The single slope solar still is mounted on angle plate made of cast steel (to prevent from the corrosion) and it is movable to make adjustment the angle of the axis of the solar still. The thickness of FRP body is kept as $0.006 \mathrm{~m}$. The basin area of the solar still is kept as $2 \mathrm{~m}^{2}$ ( $2.0 \mathrm{~m}$ length $* 1.0 \mathrm{~m}$ width at base). The heights of the solar still at lower and higher sides are $0.40 \mathrm{~m}$ and $0.70 \mathrm{~m}$ respectively, which make covering glass inclined where, an evaporation water can condensed on it. The bottom surface and sides of the solar still is painted black to have high absorptivity of solar radiation. Holes are also, drilled in the body of solar still to fix the thermocouple to monitor temperature of water, inner condensing cover and vapor. The solar still consists of the main parts as shown in schematic diagram (Fig. 1), and the following are details of its components:

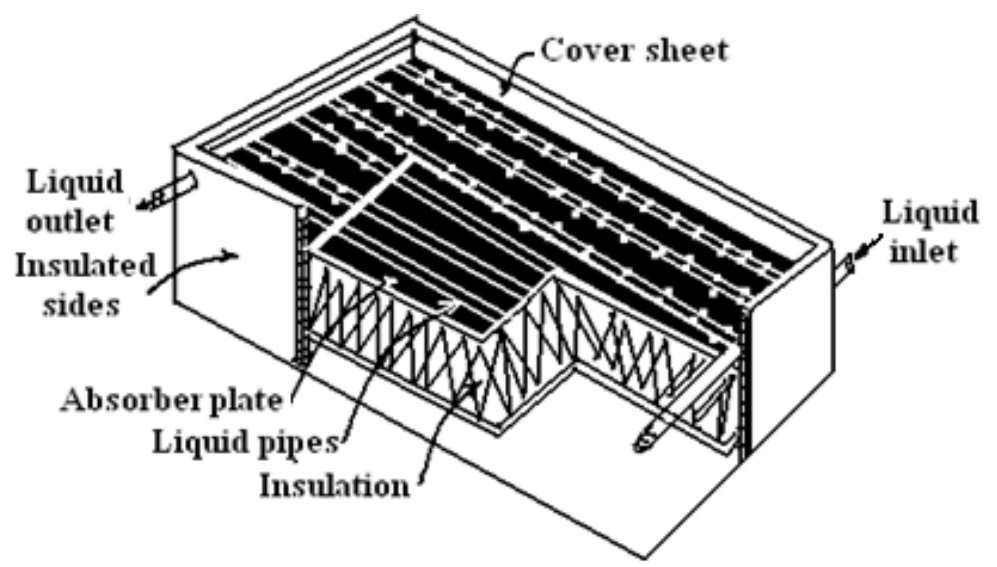

Fig. (2): The components of the liquid flat-plate solar collector. 
3.1. Basin Liner: The basin Liner is a major part of the solar still, because it absorbs the incident solar radiation that is transmitted through the glass cover. Solar radiation that passes through the transparent roof heats water in the blackened basin, thus evaporating water which gets condensed on the cooler underside of the glass cover. The basin liner should be resistant to hot saline water and it should be easily repaired.

3.2. Insulating Material: A fiber glass wool $\left(24 \mathrm{~kg}\right.$. $\left.\mathrm{m}^{-3}\right)$ with thickness of $0.05 \mathrm{~m}$ and a thermal conductivity of $0.045 \mathrm{~W} \cdot \mathrm{m}^{-2} .{ }^{\circ} \mathrm{C}^{-1}$ is used to insulate the bottom and side walls of the solar still. The insulation material is used to reduce the heat losses from the bottom and the side walls of the solar still.

3.3. Glass cover: The top of the basin is covered with glass of thickness $0.004 \mathrm{~m}$, inclined at the optimum tilt angle for the time of year in which the solar device is intended to operate and orientated to face the south direction to receive the maximum possible solar radiation. The glass cover has been sealed with silicon rubber, which is most successful because, it will make strongly contact between the glass and many other materials.

3.4. Water faucet: A water faucet is provided at the end of the lower side of the basin for washing accumulated salt and to drain water and impurities for cleaning of solar still.

3.5. Siphon float: A Siphon float and siphon float control valve are provided at the bottom of the basin to adjust the hot saline water (seawater) depth on it.

3.6. Air suction pump: The DC air suction pump of size $40 \mathrm{~W}$ is used to evacuate air from the airtight basin of solar still. The pump is driven directly by the DC power. The air suction pump operates automatically by using contactor to maintain the air pressure inside the airtight basin of the solar still at the required level.

3.7. Distillate channel: The distillate channel used to collect the condensate water from the lower edge of glass cover and carry it for the storage tank.

\section{B. Some chemical analysis of seawater:}

A salty seawater sample was taken to measure the salinity value and to determine its chemical analysis. The electrical conductivity of the salty 
water sample was $54.3 \mathrm{mmoh} / \mathrm{cm}$ at $25{ }^{\circ} \mathrm{C}$. Some chemical analysis of seawater sample which used in this study were determined at the laboratory of Soil and Water Dept., Fac., Agric., Fayoum University, and presented in Table (1).

Table (1): Some chemical analysis of seawater sample.

\begin{tabular}{|c|c|c|c|c|c|c|c|c|}
\hline \multicolumn{4}{|c|}{ Cations, (meq/) } & \multicolumn{3}{|c|}{ Anions, (meq/) } & \multirow{2}{*}{$\begin{array}{c}\mathrm{Ec} \\
(\mathrm{mmoh} / \mathrm{cm})\end{array}$} & \multirow[b]{2}{*}{ PH } \\
\hline $\mathrm{Mg}$ & $\mathrm{Ca}$ & $\mathbf{K}$ & $\mathrm{Na}$ & CL & $\mathrm{SO}_{4}$ & $\mathrm{HCO}_{3}$ & & \\
\hline 53.2 & 16.4 & 6.6 & 201.7 & 257.8 & 17.7 & 2.3 & 54.3 & 7.7 \\
\hline
\end{tabular}

\section{Meteorological measurements and instrumentation:}

1. Measurement of temperature: Copper $(100 \% \mathrm{Cu})$-constantan $(55 \%$ $\mathrm{Cu}+45 \% \mathrm{Ni}$ ) thermocouples were used to measure water, water vapor and condensing cover temperature. Thermocouples were calibrated with the help of zeal thermometer (standard thermometer). The ambient air temperature is recorded with the help of a calibrated digital thermometer (model Omega type J, USA) having a least count of $1^{\circ} \mathrm{C}$.

2. Measurement of solar radiation: Solar radiation intensity (I, W. $\mathrm{m}^{-2}$ ) was measured daily from sunrise to sunset outside the experimental setup. The solar radiation flux incident on a horizontal surface was measured using a data acquisition system (TENMARS - Solar Power Meter - TM206), with a measurement of 0.0 to $1999 \mathrm{~W} \cdot \mathrm{m}^{-2}$ and an accuracy of $0.1 \mathrm{~W}$. $\mathrm{m}^{-2}$ over a spectral range of 300 to $1100 \mathrm{~nm}$. Data were collected daily by a data logger at each $10 \mathrm{~min}$. and averaged over a time of $1 \mathrm{hr}$. interval.

3. Measurement of distillate yield: The condensed water is collected in a galvanized iron channel fixed at the lower end side of the solar still glass cover. The distillate water collected is continuously drained through flexible pipe and stored in a storage tank placed outside the solar still. The collected distillate yield has been measured using graduated cylinder with least count of $1 \mathrm{ml}$.

D. Experimental procedure: Daily experiment on single slope solar still (passive solar still) and same coupled with liquid flat plate collector. The response of the solar still unit to the solar energy obtained in two different months of the year (January and June, 2014), two water flow rates (3.79 L.min 1 and 5.69 L. $\left.\mathrm{min}^{-1}\right)$ and three levels of water depth $(1.5 \mathrm{~cm}, 2.5 \mathrm{~cm}$ 
and $4 \mathrm{~cm}$ ) were investigated. The hourly average incident solar radiation on the horizontal surface was measured, while the hourly average solar radiation incident on, absorbed by, gained in the solar collector inclined at the optimum tilt angle and the solar collector efficiency for the months of January and June (2014) were calculated. The time from sunrise to sunset ranged from 8:00 am to 5:00 pm for January and from 6.00 am to $7.00 \mathrm{pm}$ for June. Because the amount of solar radiation at the first hour of sunrise is low, the outlet water temperature of the liquid solar collector is, also, low. Thus, in order to achieve efficient water distillation, it was decided to operate the system from 9.00 am to $6 \mathrm{pm}$ for January and from7.00 am to $8.00 \mathrm{pm}$ for June. The temperatures of seawater, glass covers, water vapors and ambient temperatures are continuously recorded with help of inbuilt thermocouples.

E. Thermal Performance of liquid flat plate solar collector: The thermal performance of this solar collector was estimated using the following equations:

\section{Hourly average solar energy available on collector surface $\left(q_{a v}\right)$ :}

The hourly average solar radiation received by the specific tilted surface of the solar collector was calculated using the following formula:

$$
\mathbf{Q}_{\mathrm{i}}=\mathbf{I} \times \mathbf{A} \text {, (Watt) }
$$

Where: $\mathrm{Q}_{\mathrm{i}}$ is the hourly average solar radiation received by the specific tilted surface of the solar collector (W), I is the solar radiation flux on the tilted solar collector, $\left(\mathrm{W} . \mathrm{m}^{-2}\right)$ and $\mathrm{A}$ is the surface area of the solar collector, $\left(\mathrm{m}^{2}\right)$.

2. The Hourly Average Absorbed Solar Radiation $\left(\mathbf{Q}_{\mathbf{s}}\right)$ : As it is shown in Fig. (3), a part of received radiation is reflected back to the sky, another component is absorbed by the glazing and the rest is transmitted through the glazing and reaches the absorber plate as short wave radiation. Thus, the hourly average total absorbed solar radiation by the solar collector absorber plate can be estimated from the following equation:

$$
\mathbf{Q}_{\mathrm{s}}=\mathbf{Q}_{\mathrm{i}}(\tau \boldsymbol{\tau})_{\mathrm{av}}=\mathbf{I} \times \mathbf{A}(\tau \boldsymbol{\tau}),(\text { Watt })
$$

Where: $(\tau \alpha)$ is the optical efficiency, which can be calculated as follows:

$$
\begin{gathered}
(\tau)_{\mathrm{av}}=\tau_{\max }-0.00437 \exp ^{(0.0936(\theta-30))} \\
(\alpha)_{\mathrm{av}}=\alpha_{\max }-0.00476 \exp ^{(0.0940(\theta-35)}
\end{gathered}
$$


Where: $\tau$ is the solar transmittance of the glass cover at the given tilt angle $(\theta)$ of the solar collector $(-) ; \alpha$ is the average absorptivity for solar energy (-).

3. Heat loss from the solar collector $\left(\mathbf{Q}_{\mathbf{0}}\right)$ : As the collector absorbs heat its temperature is getting higher than that of the surrounding and heat is lost to the atmosphere by convection and radiation. The rate of heat loss (Qo) can be estimated from the following equation:

$$
\mathbf{Q}_{\mathbf{0}}=\mathbf{U}_{\mathbf{L}} \mathbf{A}\left(\mathbf{T}_{\mathbf{c}}-\mathbf{T}_{\mathbf{a}}\right),(\text { Watt})
$$

Where: $\mathrm{U}_{\mathrm{L}}$ is the collector overall heat transfer coefficient, $\left(\mathrm{W} \cdot \mathrm{m}^{-2} \cdot{ }^{\circ} \mathrm{C}\right)$.

$\mathrm{T}_{\mathrm{c}}$ and $\mathrm{T}_{\mathrm{a}}$ are the collector and ambient temperatures, $\left({ }^{\circ} \mathrm{C}\right)$.

4. Useful heat energy gain $\left(\mathbf{Q}_{\mathbf{u}}\right)$ : The rate of useful energy extracted by the collector, expressed as a rate of extraction under steady state conditions, is proportional to the rate of useful energy absorbed by the collector, less the amount lost by the collector to its surroundings. The useful heat energy gain is calculated as follows:

$$
Q_{u}=Q_{i}-Q_{o}=I(\tau \alpha) A\left(T_{c}-T_{a}\right),(\text { Watt }),
$$

It is also known that the rate of extraction of heat from the collector may be measured by means of the amount of heat carried away in the fluid passed through it, that is:

$$
\left.Q_{u}=\mathbf{m ~ C p}\left(\mathbf{T}_{\mathbf{o}}-\mathbf{T}_{\mathrm{i}}\right) \text {, (Watt }\right)
$$

Where: $\mathrm{m}$ is the water mass flow rate, $\left(\mathrm{kg} . \mathrm{s}^{-1}\right)$; $\mathrm{Cp}$ is the specific heat of water, $\left(\mathrm{J}^{\mathrm{kg}} \mathrm{kg}^{-1} \cdot{ }^{\circ} \mathrm{C}^{-1}\right) ; \mathrm{T}_{\mathrm{o}}$ and $\mathrm{T}_{\mathrm{i}}$ are the outlet and inlet water temperatures of the solar collector, $\left({ }^{\circ} \mathrm{C}\right)$.

Equation (6) proves to be somewhat inconvenient because of the difficulty in defining the collector average temperature. It is convenient to define a quantity that relates the actual useful energy gain of a collector to the useful gain if the whole collector surface were at the fluid inlet temperature. This quantity is known as "the collector heat removal factor (FR)" and is expressed as:

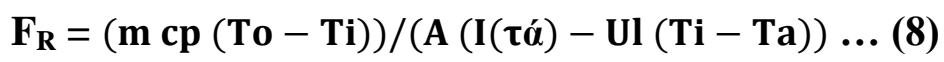

The maximum possible useful energy gain in a solar collector occurs when the whole collector is at the inlet fluid temperature. The actual useful energy gain $(\mathrm{Qu})$, is found by multiplying the collector heat removal factor (FR) by the maximum possible useful energy gain. This allows the rewriting of equation (6): 


$$
Q_{u}=F_{R} A\left[I(\tau \alpha)-U_{L}\left(T_{i}-T_{a}\right)\right]
$$

$\mathrm{Eq}(9)$ is a widely used relationship for measuring collector energy gain.

5. The thermal efficiency of the solar collector $\left(\eta_{c}\right)$ : A measure of a flat plate collector performance is the collector efficiency $\left(\eta_{c}\right)$, which defined as the ratio of the useful energy gain $(\mathrm{Qu})$ to the incident solar energy $\left(\mathrm{Q}_{\mathrm{i}}\right)$ over a particular time period:

$$
\dot{\eta}_{\mathrm{c}}=\int \mathbf{Q u} \mathbf{d t} / \mathbf{A} \int \mathbf{I} \mathbf{d t}
$$

The instantaneous thermal efficiency of the collector is:

$$
\begin{aligned}
& \dot{\eta}_{\mathrm{c}}=\boldsymbol{Q u} /(\boldsymbol{I} A) \\
& \dot{\eta}_{c}=F_{R} A\left(I(\tau \alpha)-U_{L}\left(T_{i}-T_{a}\right) /(I . A)\right.
\end{aligned}
$$

Finally, the thermal efficiency of the solar collector is calculated as follows:

$$
\eta_{c}=F_{R}(\tau \alpha)-F_{R} U_{L}\left(T_{i}-T_{a}\right) / I, \quad(\%)
$$

\section{RESULTS AND DISCUSSIONS}

1. Hourly average total solar radiation: The hourly average total solar radiation incident on the horizontal surface was measured, while the hourly average solar radiation incident on, absorbed by and gained in the solar collector inclined at the optimum tilt angle for the months of January and June (2014) were estimated and the results were illustrated in Fig. (3 - a and b). The results indicated that, the hourly average total solar radiation incident on, absorbed by and gained in the solar collector inclined at the optimum tilt angle for both months almost clarified the same trend of that incident on the horizontal surface, while, the maximum values occurred at 12:00 noon. The total amount of incident solar radiation on the tilted surface is higher than the incident solar radiation on the horizontal surface for both months. Consequently, the tilted surface of the solar collector inclined with an optimum tilt angle for January $\left(45^{\circ}\right)$ and June $\left(5^{\circ}\right)$ increased the solar energy by $27.3 \%$ and $22.63 \%$ respectively, because the tilt angle causes the beam-radiation to be perpendicular on the collector surface at and around noon. The absorbed solar radiation (12.5 $\mathrm{MJ} \mathrm{m}^{-2}$. $\left.\mathrm{day}^{-1}\right)$ by the collector plate is slightly higher than that incident on the horizontal surface $\left(11.02 \mathrm{MJ} \mathrm{m}^{-2}\right.$.day $\left.{ }^{-1}\right)$ for the month of January, whereas the corresponding values of absorbed solar radiation (24.9 $\mathrm{MJ} \mathrm{m}^{-2} \cdot \mathrm{day}^{-1}$ ) for the month of June is lower than that 
incident on the horizontal surface $\left(28.22 \mathrm{MJ} \mathrm{m}^{-2}\right.$. day $\left.{ }^{-1}\right)$ because the solar collector was titled at the optimum tilt angle $\left(5^{\circ}\right)$, which is almost near the horizontal. On the other hand, the results showed that the hourly average total useful energy gained was directly related to some factors such as: solar intensity (I), difference between the outlet and inlet air temperatures of the solar collector and the mass of water flow rate. The values of hourly average total useful energy gained were estimated with water flow rate of $3.79 \mathrm{~L} \cdot \mathrm{m}^{-1}$. The maximum value of the hourly average useful energy gained were achieved at 12:00 noon, because at this period the maximum solar intensity and higher difference between the outlet and inlet air temperatures occurred. From the results of solar energy estimations, it can be concluded that the maximum amount of total daily solar radiation gained in the solar collector $\left(5.45 \mathrm{MJ} \mathrm{m}^{-2}\right.$.day ${ }^{-1}$ and 11.50 $\mathrm{MJ} \mathrm{m^{-2 }}$.day ${ }^{-1}$ for the months of January and June, respectively) under Fayoum conditions was obtained when the solar collector was oriented at south direction and tilted at the optimum tilt angle for both months.

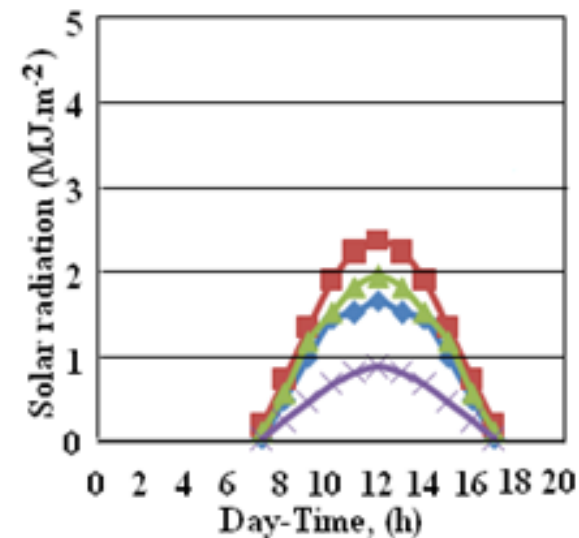

(a) January

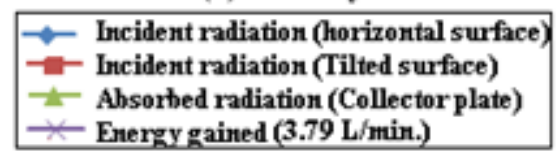

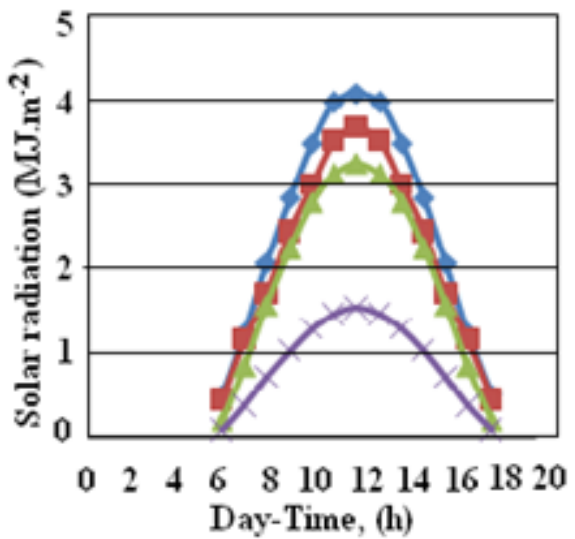

(b) Jume

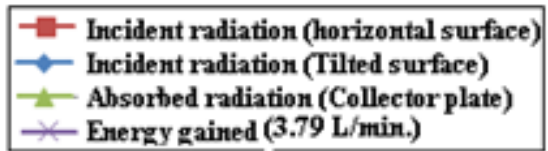

Fig. (3): Hourly average solar radiation incident on, absorbed by and gained in the solar copllector inclined at the optimun tilt angle for Fayoum, Egypt, 2014.

2. Hourly average thermal efficiency of the liquid solar collector: The hourly average thermal efficiency of the solar collector was calculated for 
the month of June at two different water mass flow rates 3.79 L.min 1 and 5.69 L. $\mathrm{min}^{-1}$ ) and the results are illustrated in Fig. (4). The obtained results indicated that the hourly average thermal efficiency of the solar collector almost clarified the same trend of the useful energy gained, where the maximum value occurred at 12:00 noon. The results revealed that the maximum hourly average overall thermal efficiency for the solar collector tilted at the optimum angle with the higher water flow rate was $45.1 \%$, which is relatively higher than that $(39.8 \%)$ with the lower water flow rate. Consequently, the solar collector with the higher water flow rate increased the hourly average overall thermal efficiency of the solar collector by $13.32 \%$ as compared with that of the lower airflow rate. The daily average collector efficiency was calculated and found to be $36 \%$. Thus, for the purpose of solar water distillation, the maximum solar energy collection is desired for a given month to maximize the amount of solar energy gained by the solar distillation unit and consequently increasing its efficiency.

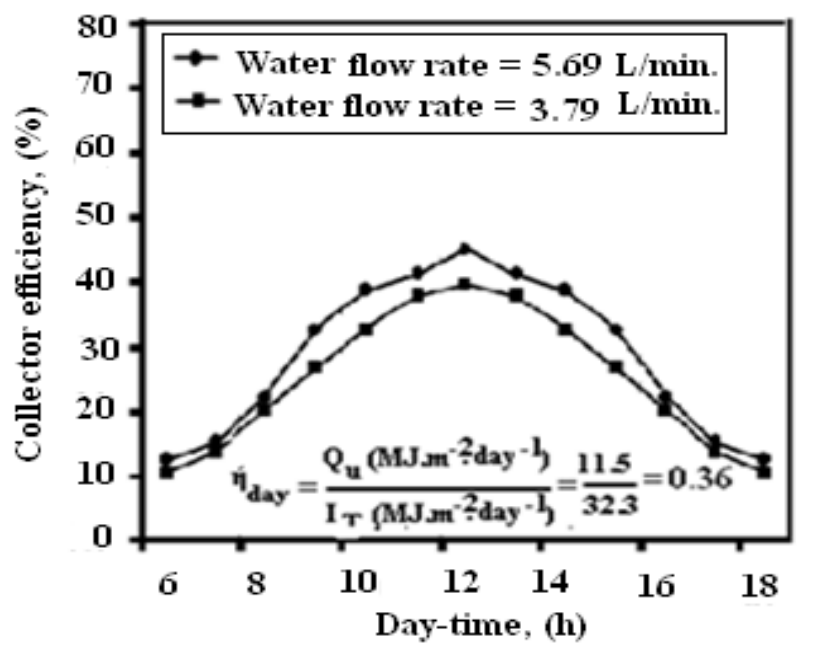

Fig. (4): Estimated values of hourly average solar collector efficiency at two different water flow rates for Fayoum, Egypt, at June 2014.

3. Outlet water Temperatures of the Solar Collector: The hourly average ambient temperatures $\left(\mathrm{T}_{\mathrm{a}}\right)$ for Fayoum, Egypt and the outlet water temperatures of the solar collector $\left(\mathrm{T}_{\mathrm{o}}\right)$ tilted at the optimum tilt angle $\left(45^{\circ}\right.$ for January and $5^{\circ}$ for June) were measured at two different 
water flow rates $\left(3.79\right.$ L.min. ${ }^{-1}$ and 5.69 L.min. $^{-1}$ ) and the results are graphically illustrated in Fig. (5). The results showed that, the outlet water temperature of the solar collector at the two water flow rates were higher in most of the day-time (from 6 am to $8 \mathrm{pm}$ ) as compared with the corresponding values of the ambient temperature and almost take the same trend. As shown in Fig. (5-a) for the month of January, the maximum values of the outlet temperatures for the solar collector with water flow rates of $3.79 \mathrm{~L} . \mathrm{min}^{-1}$ and $5.69 \mathrm{~L}^{-m i n} .^{-1}$ were recorded to be $42.6{ }^{\circ} \mathrm{C}$ and $37.8{ }^{\circ} \mathrm{C}$, respectively, (at 2:0 $0 \mathrm{pm}$ ), whereas, the ambient air temperature reached to the maximum value of $18.2^{\circ} \mathrm{C}$ (at $2 \mathrm{pm}$ ). As shown in Fig. (5-b) for the month of June, the maximum values of the outlet temperatures for the solar collector with water flow rates of $3.79 \mathrm{~L} . \mathrm{min}^{-1}$ and 5.69 L.min. ${ }^{-1}$ were recorded to be $59.6{ }^{\circ} \mathrm{C}$ and $49.8{ }^{\circ} \mathrm{C}$, respectively, (at $2 \mathrm{pm}$ ), whereas, the ambient air temperature reached to the maximum value of $36.6{ }^{\circ} \mathrm{C}$ (at 2:00 pm). The outlet water temperatures of the solar collector with the lower water flow (3.79 L. $\mathrm{min}^{-1}$ ) were higher as compared with the corresponding values of the outlet temperatures with higher water flow rate $\left(5.69 \mathrm{~L} . \mathrm{min}^{-1}\right)$. Thus, the outlet water temperature from the solar collector (Inlet water temperature to the basin of solar still) increased as the water flow rate decreased.

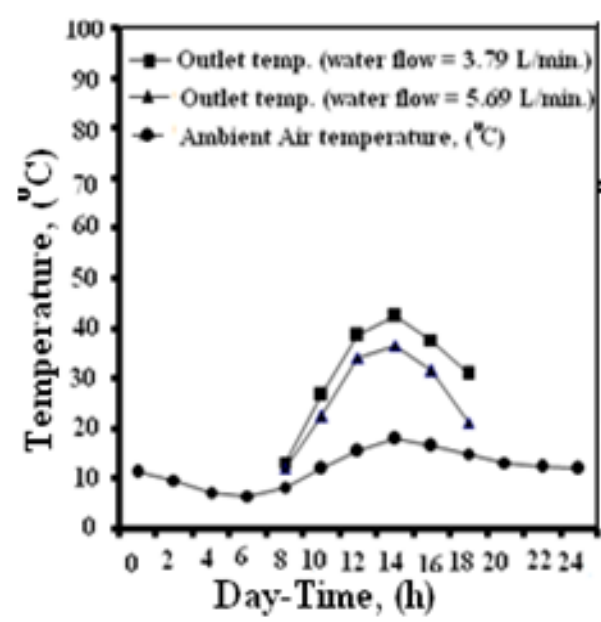

(a) January

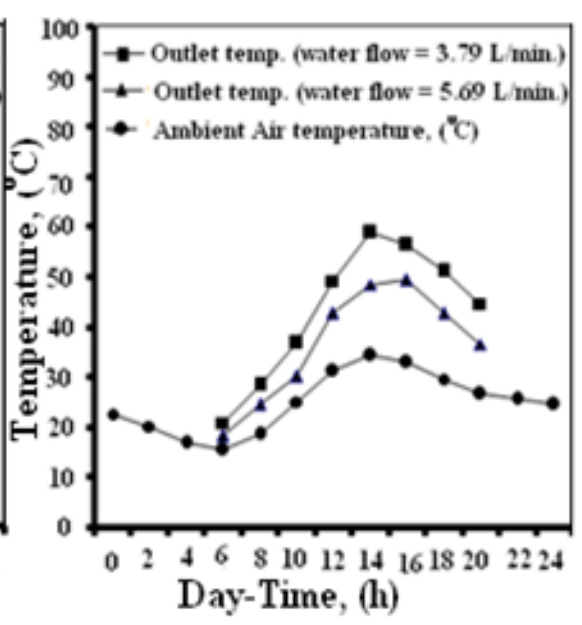

(b) June

Fig. (5): Hourly average ambient and water outlet temperatures of solar collector tilted at the optimum tilt angle with two different water flow rates for Fayoum, 2014. 
4. Temperature distribution of solar still: Fig. (6 - a and b) shows variations of ambient, glass cover, and basin water temperatures of solar still coupled with liquid flat plate collector working at water flow rate 5.69 L.min. ${ }^{-1}$. The maximum outlet water temperatures of the solar collector $\left(\mathrm{T}_{\mathrm{o}}\right)$ with water flow rate of 5.69 L.min. ${ }^{-1}$ for the months of January and June water flow rate of 5.69 L.min. ${ }^{-1}$ were $37.8{ }^{\circ} \mathrm{C}$ and $49.8{ }^{\circ} \mathrm{C}$, respectively. The results indicated that ambient, glass cover, and basin water temperatures increase as time go on to a maximum value at $2.00 \mathrm{pm}$ and all decrease after that. The basin water temperature has the higher values followed by glass cover temperature, followed by ambient temperature during the time of the day.

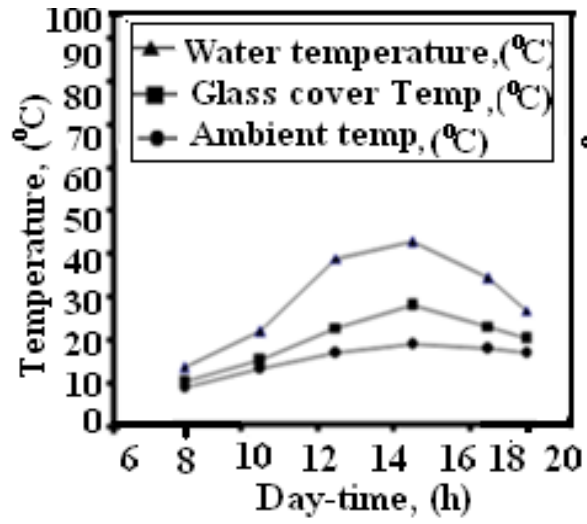

(a) January

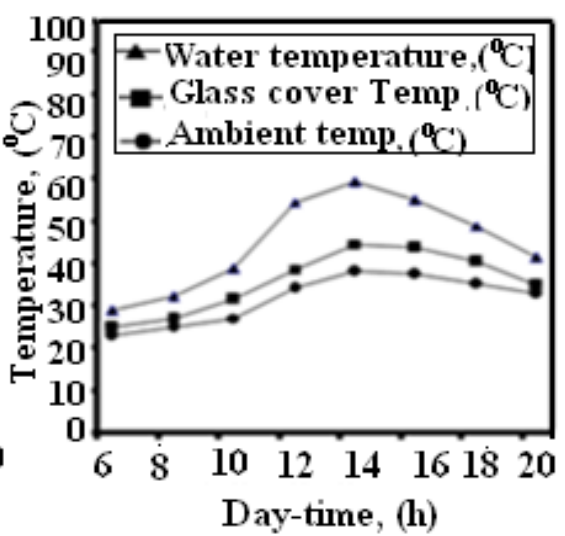

(b) Jume

Fig. (6): Daily variation of ambient, glass cover and basin water temperatures of solar still coupled with liquied flat-plate collector for Fayoum, Egypt, 2014

\section{Effect solar radiation intensity on distillated water productivity:}

The solar radiation intensity is the most important parameter affecting the performance of the solar distiller. Fig. (7) shows the average daily output of the single solar still coupled with liquid flat plate collector when the covers tilt are at optimum angle of $5^{\circ}$ for the month of June. Thus, the distillated water productivity increases as solar radiation increases and vice versa. An equation was developed by the Excel-2003 soft-ware, which has the following formula:

$$
D_{w}=0.684 e^{0.084 I}
$$

Where: $D_{w}$ is the distillated water productivity, $\left(\mathrm{L} \cdot \mathrm{m}^{-2} \cdot\right.$ day $\left.^{-1}\right)$, and $\mathrm{I}$ is the 
solar radiation intensity (MJ.m ${ }^{-2}$. day ${ }^{-1}$ ).

The experiment was conducted at fifteen days of each two different months (January and June, 2014). Fig. (8) shows the average daily output of the single solar still coupled with Liquid flat plate collector when the cover tilt is at optimum angle of $45^{\circ}$ for January and $5^{\circ}$ for June. It shows that the solar still productivity is proportional to the solar intensity, which depends on climate conditions of the place where it get installed. Thus, the maximum solar still yield occurs in June, where the solar radiation intensity is also maximum compared to January. The solar still output for

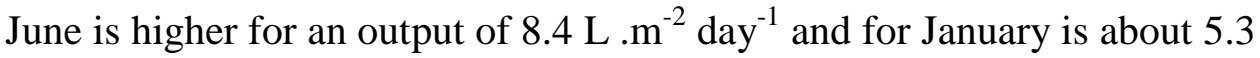
L. $\mathrm{m}^{-2}$.day ${ }^{-1}$.
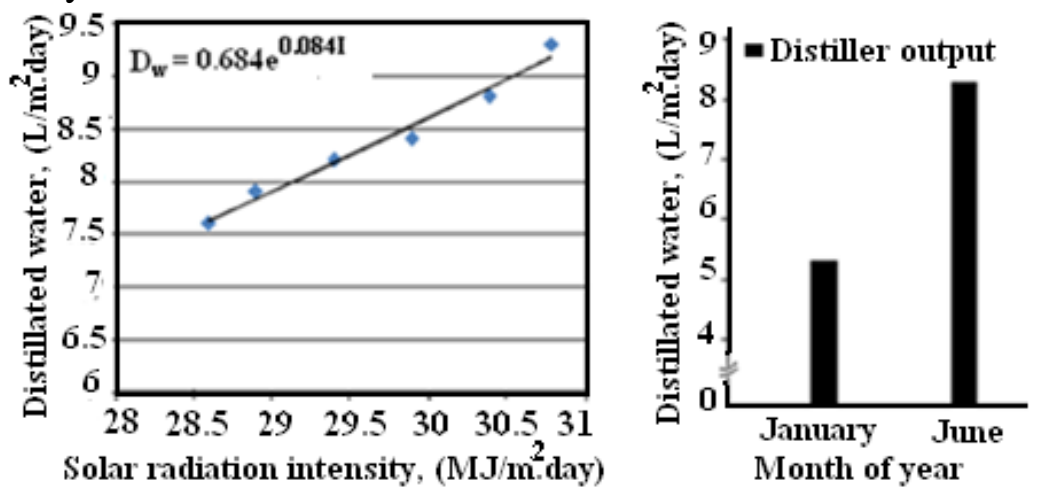

Fig. (7): Effect of solar radiation intensity on solar still output for June, 2014.

Fig. (8): Average daily distillated water from solar still for January and June, 2014.

\section{Effect of coupling a solar still with liquid flat plate collector: Daily} experiments on single slope solar still (passive solar still) and same coupled with flat plate collector (active solar still) were carried out at two months (January and June, 2014) with water depth of $2.5 \mathrm{~cm}$. The effect of coupling a solar still with liquid flat plate collector is as shown in Fig. (9). There is proportionality in water production with respect to the basin water temperature means the higher basin water temperature, higher rate of evaporation and more yield from solar still. Also, the higher the temperature of water inside the basin, higher the distillate output from the solar still. This high productivity is gained by the solar still coupled with flat plate collector. This is explained by fact that when temperature of water inside the tubes of the liquid flat plate collector will heated by the incoming solar radiation, hence the water temperature will be increased 
and such kind of preheated water will be used in solar still, so less heat is required to evaporate the water into steam and higher distillate output is enhanced by solar still. Also, evacuating air from the airtight basin of solar still will help in evaporating water at low temperatures, and enhancing the amount of distilled water especially in the winter months. For the month of January, the percentage enhancement in daily productivity of solar still coupled with liquid flat plate collector $(5.3 \mathrm{~L} . \mathrm{m}$ ${ }^{2}$.day $^{-1}$ ) is calculated and found to be $26.2 \%$ more than when solar still operated alone $\left(4.2 \mathrm{~L} \cdot \mathrm{m}^{-2} \cdot \mathrm{day}^{-1}\right)$. While, for the month of June, the percentage enhancement in daily productivity of solar still coupled with liquid flat plate collector, $\left(8.4 \mathrm{~L} \cdot \mathrm{m}^{-2} \cdot \mathrm{day}^{-1}\right)$ is calculated and found to be $29.2 \%$ more when solar still operated alone $\left(6.5 \mathrm{~L}^{-\mathrm{m}^{-2}}\right.$. day $\left.{ }^{-1}\right)$.

\section{Effect of water depth on the productivity of the solar distiller:}

Fig. (10) shows the productivity of the solar still coupled with solar collector at water flow rate of $3.79 \mathrm{~L} . \mathrm{min}^{-1}$ for three different basin water depths $(1.5,2.5$ and $4 \mathrm{~cm})$ for June, 2014. It is clear that, the productivity of solar still decreases with increase of water depth. Hence, to increase the productivity of solar still, water depth inside the basin should be lower and water quantity should be remain constant. It is clear that from Fig. (10), the $1.5 \mathrm{~cm}$ water depth gave better performance compared with 2.5 $\mathrm{cm}$ water depth as well as $4 \mathrm{~cm}$ water depth. We can also say that, when water depth decreases inside the basin of the solar still, heat capacity of basin decreases and results in higher temperature inside the solar still and better evaporation and condensation produces higher quantity of distillate output.

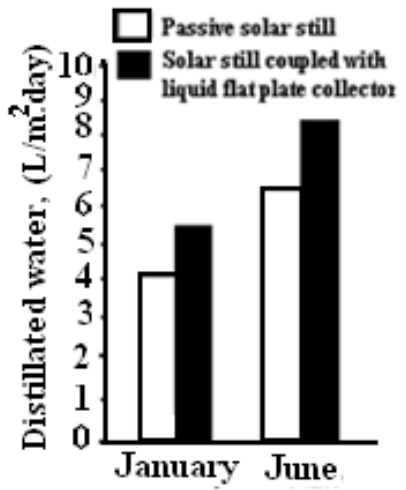

Fig. (9): Comparision of alone solar still versus solar still coupled with liquid flat-plate collector.

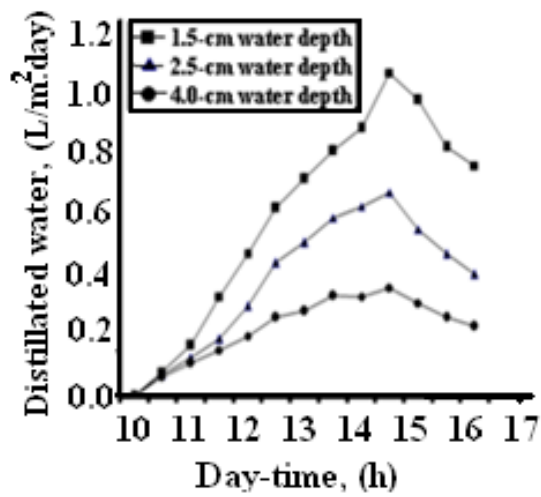

Fig. (10): Effect of water depth on solar still productivity. 


\section{CONCLUSION}

1. The surface of the solar collector inclined with an optimum tilt angle for January $\left(45^{\circ}\right)$ and June $\left(5^{\circ}\right)$ increased the solar radiation incident on the horizontal surface by $27.3 \%$ and $22.63 \%$ respectively.

2. The higher water flow rate $\left(5.69 \mathrm{~L} . \mathrm{min}^{-1}\right)$ increased the hourly average overall thermal efficiency of the solar collector by $13.32 \%$ as compared with the lower water flow rate $\left(3.79\right.$ L.min. ${ }^{-1}$ ).

3. The outlet water temperatures of the solar collector with the lower water flow rate $\left(3.79 \mathrm{~L}_{\mathrm{min}}{ }^{-1}\right)$ were higher as compared with the corresponding values of the outlet temperatures with higher water flow rate (5.69 ${\mathrm{L} . \mathrm{min}^{-1}}^{-1}$ ), and thus, the outlet water temperature from the solar collector (Inlet water temperature to the basin of solar still) increased as the water flow rate decreased.

4. From solar still yield vs. solar radiation intensity graph, it is found that solar still yield is directly proportional to the intensity of solar radiation.

5. Evacuating air from the airtight basin of solar still helps in evaporating water at low temperatures, and enhancing the amount of distilled water especially in the winter months.

6. The higher solar still yield occurs in June, where the solar radiation intensity is also higher compared to January, and thus, the solar still output for June was higher for an output of about $8.4 \mathrm{~L} \cdot \mathrm{m}^{-2}$.day ${ }^{-1}$, while for January was about $5.3 \mathrm{~L} \cdot \mathrm{m}^{-2}$.day ${ }^{-1}$.

7. For the month of January, the percentage enhancement in daily productivity of solar still coupled with liquid flat plate collector (5.3 L. $\mathrm{m}^{-2}$.day ${ }^{-1}$ ) is calculated and found to be $26.2 \%$ more than when solar still operated alone (4.2 L.m ${ }^{-2}$.day ${ }^{-1}$ ).

8. For the month of June, the percentage enhancement in daily productivity of solar still coupled with liquid flat plate collector (8.4 L. $\mathrm{m}^{-2}$.day $\left.{ }^{-1}\right)$ is calculated and found to be $29.2 \%$ more when solar still operated alone (6.5 L.m ${ }^{-2}$.day $\left.{ }^{-1}\right)$.

9. Under the conditions of this study, the optimum depth to distillate water by using solar still coupled with liquid solar collector is $1.5 \mathrm{~cm}$. 


\section{REFERENCES}

Bouker, M. and Harmin, A. (2001). Effect of climate conditions on the performance of a simple basin solar still. A comparative study. Desalination. 137. 15-22, (2001).

Cesare, S. (2001). Survey of energy resources - solar energy, World Energy Council, London, UK, 2001.

Garzia-Rodriguez, L. (2002). Seawater desalination driven by renewable energies: a review, Desalination, 143 (2002): pp. 103-113.

Garzia-Rodriguez L. and Gomez-Camacho, C. (2002). Comparison of solar technologies for applications in seawater desalination. Desalination 2002:142, pp. 135-142.

Gude, V. G. ; Nirmalakhandan, N.; Deng, S. and Maganti, A. (2012). Low temperature desalination using solar energy, Applied Energy, Volume 91, Issue 1, (2012): pp.466-474.

Kunze, H. (2001). A new approach to solar desalination for small- and medium-size use in remote areas. Desalination. 139, 35-41.

Hikmet, S. A.; Fuat, E. and Atikol, U. (2005). An experiment study on inclined solar water distillation system. Desalination. 180, 285-289 (2005).

Hitesh, N. P.; Mitesh, I.P.; Bakul, P.; Ranvirgiri, G. and Manish. D. (2011). A comparative analysis of single slope solar still coupled with flat plate collector and passive solar still. IJRRAS 7 (2): pp. 111-116 (2011).

Hussain, A. K. M. (2003). Solar energy utilization in Libya for seawater desalination. Proceedings at the ISES Solar World Congress 2003, Gothenburg.

Naim, M.; Mervat, A. and Abed El-Kawi, (2003). Non conventional solar stills with charcoal particles as absorber medium. Desalination, 153 (2003): pp. 55-64. 
Qiblawey, H. M. and Banat, F. (2008). Solar thermal desalination technologies. Desalination, Volume 220, Issues 1-3, (2008): pp.633644.

Sethi, A. K. and Dwivedib, V. K. (2013). Design, fabrication, and performance evaluation of double slope active solar still under forced circulation mode. Int. J. of Thermal \& Environmental Engineering. Volume 6, No. 1 (2013) 27-34.

Singh, H. N. and Tiwari, G. N. (2004). Monthly performance of passive and active solar still for different climate operation. Desalination.168. 145-1150 (2004).

UNEP, (United Nations Energy Program). (2000). http://www.unep.org/geo2000/english/0046.htm [2003-06-09].

\section{الملخص العربي \\ تصميم وتقييم أداء وحدة تقطير شمسي لتحلية مياه البحر \\ د. حمدى سالم السيد عبدالجليل}

أجرى هذا البحث بهدف تصميم وتقييم آداء وحدة تقطير شمسى لتحلية التيلة مياه البحر , حيث تم تصميم

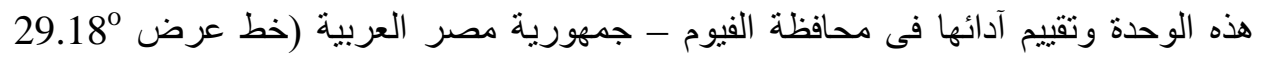

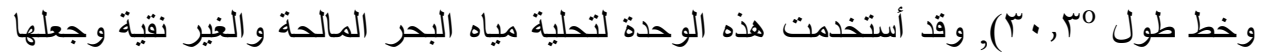

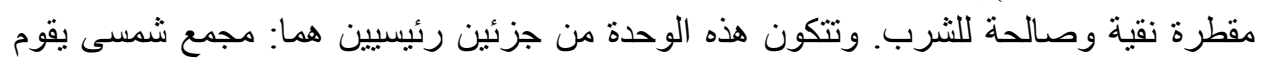

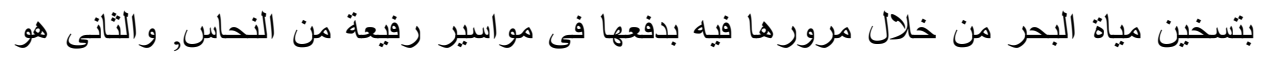

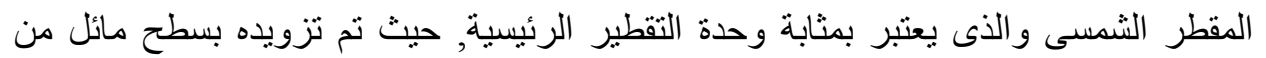

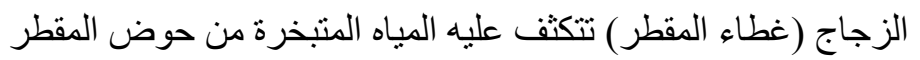

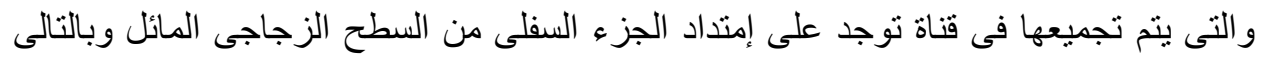

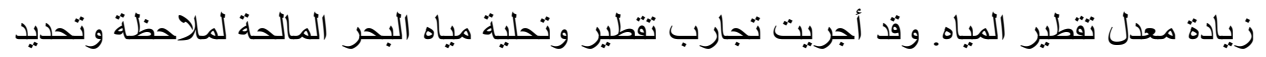

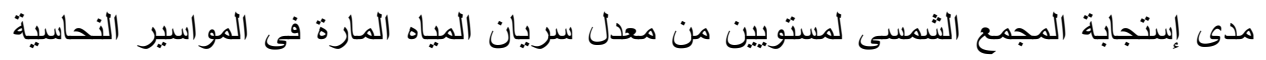

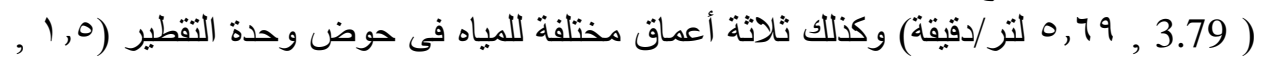

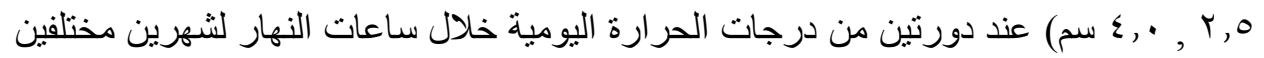

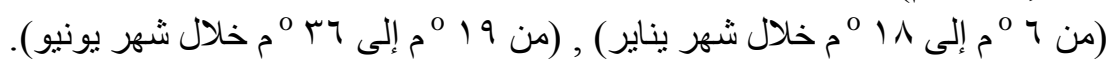
وقد أوضحت نتائج الدر اسة ما ماليلي:

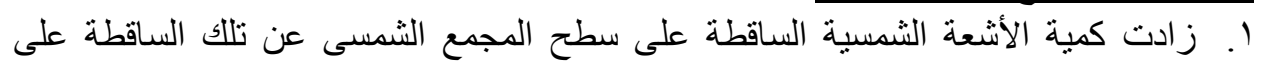

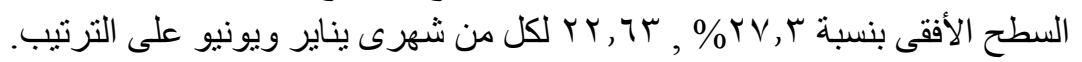

أستاذ مساعد الهندسة الزراعية - كلية الزراعة - جامعة الفيوم. 


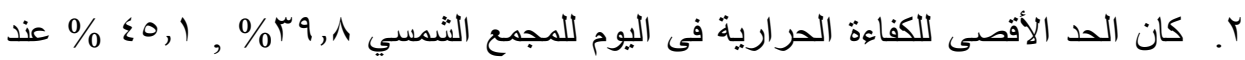

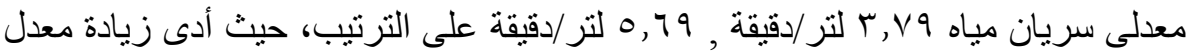

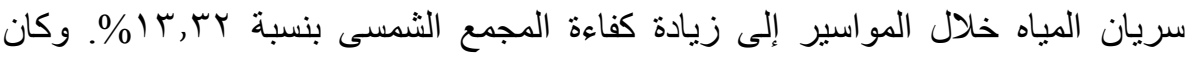

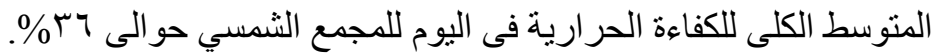

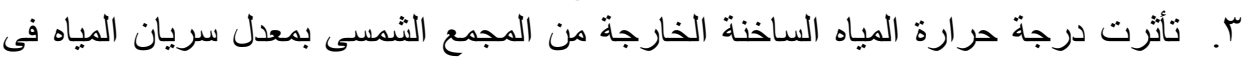
المو اسير, حيث كانت أقصى درجة حر ارة للمياه الساخنة الخارجة من المجمع الثمسئ الثمى أثناء

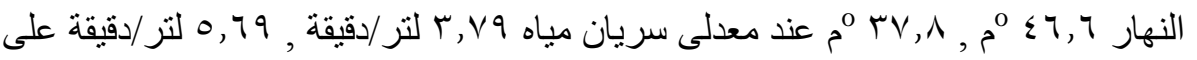
الترتيب فى شهر يناير, بينما كانت

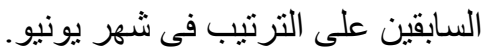

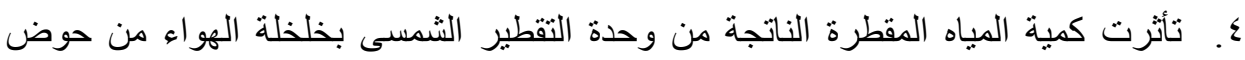
المقطر (تبخير المباه تحت ضغط سالب), حيث أدى شفط الهو اء وتفريغ حوض وضدة وحدة التقطر من الهو اء إلى تبخير كمية كبيرة من المياه عند درجات حرارة منخفضة وبذللك يمكن الحصول على قدر كبير من المياه المقطرة (العذبة و الصالحة للشرب) في فئ فصل الثنتاء حيث حيث تكون حر ارة الثمس ضعيفة.

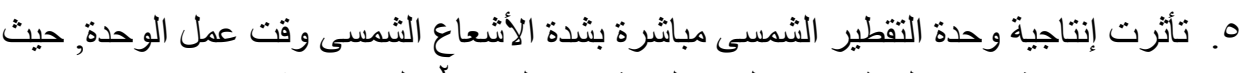

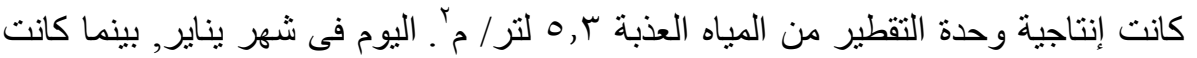

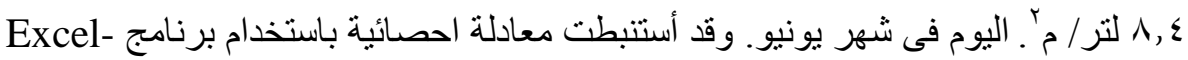
2003 وذللك للتنبؤ بإنتاجية وحدة التقطير الثمسى من المياه العذبة كدالة لثدة الأشعاع

$$
\mathrm{D}_{\mathrm{w}}=0.684 \mathrm{e}^{0.084 \mathrm{I}}
$$

الثمسى، وكانت المعادلة كالنالي:

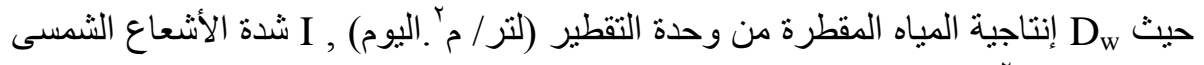

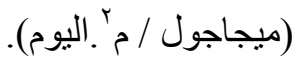

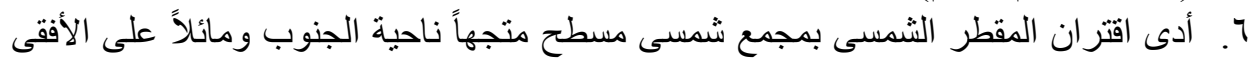

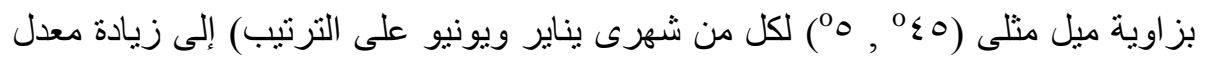

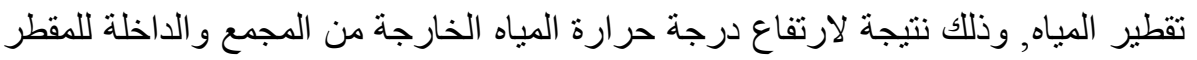

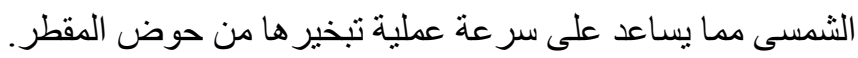
V. فى شهر يناير, أدى أقتران المقطر الثمسى بالمجمع الثمسى إلى زيادة معدل إنتاجية وحدة

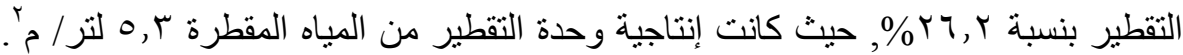

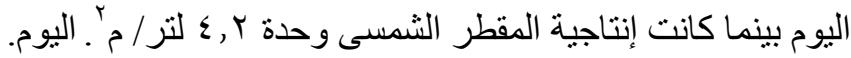
^. فى شهر يونيو, أدى أقتر ان المقطر الشمسى بالمجمع الشمسى إلى زيادة معدل إنتاجية وحدة

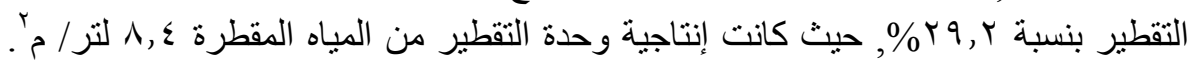

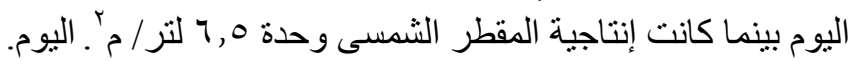

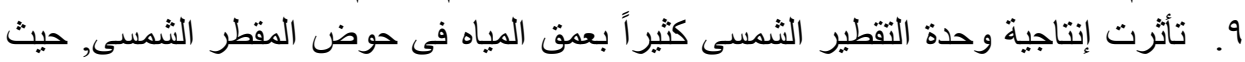

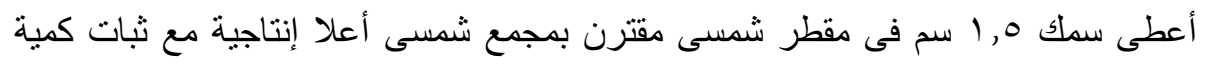

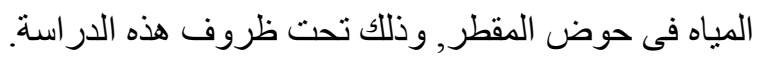

